\title{
Determination of the Substrates for Sulphate-reducing Bacteria within Marine and Estuarine Sediments with Different Rates of Sulphate Reduction
}

\author{
By R. J. PARKES, ${ }^{*}$ G. R. GIBSON, ${ }^{2}$ I. MUELLER-HARVEY, ${ }^{1}$ \\ W. J. BUCKINGHAM ${ }^{1}$ AND R. A. HERBERT ${ }^{2}$ \\ ${ }^{1}$ Scottish Marine Biological Association, PO Box 3, Oban, Argyll PA34 4AD, UK \\ 2 Department of Biological Sciences, University of Dundee, Dundee DDI 4HN, UK
}

(Received 26 April 1988; revised 6 September 1988; accepted 12 October 1988)

\begin{abstract}
The substrates used by sulphate-reducing bacteria in sediment slurries from Loch Eil, Loch Etive and the Tay estuary were determined by selectively inhibiting sulphate reduction with $20 \mathrm{~mm}$-molybdate and measuring the resultant substrate accumulation. Substrate accumulation was linear after molybdate addition, and the rate of accumulation closely matched sulphate reduction rates, indicating that metabolic pathways other than those specifically involving sulphate reduction were not affected by the inhibitor. In sediments from all three sites acetate was a major substrate, although the percentage of sulphate reduced due to acetate oxidation varied considerably among the sites (Tay estuary, 35\%; Loch Eil, 64\%; Loch Etive, $100 \%$ ). In addition to acetate, 17 individual substrates were shown to be involved in sulphate reduction to varying extents in the Tay estuary and Loch Eil sediments; these included lactate, $\mathrm{H}_{2}$, propionate, iso- and $n$-butyrate, iso- and $n$-valerate, 2-methylbutyrate and amino acids. At both sites propionate accounted for between 6 and $12 \%$ of sulphate reduction. Butyrate ( $n$ - and iso-), iso-valerate and 2-methylbutyrate were of approximately equal importance at each site and together accounted for 13 and $11 \%$, respectively, of the sulphate reduction in the Tay estuary and Loch Eil sediments. Lactate was only important in the Tay estuary sediments, where it accounted for $43 \%$ of sulphate reduction. The rate of accumulation of amino acids was greatest in the Tay estuary sediments, but the contribution of amino acids to sulphate reduction was higher in the Loch Eil $(9 \%)$ than in the Tay estuary sediments $(2 \%)$. Of the 21 individual amino acids that were measured there was a linear increase in nine; the most important of these were serine, glutamate and arginine. In general, when sulphate reduction rates were high the substrates for this process were more varied than when rates were low. Combining the results of two experiments and assuming complete degradation of the individual substrates, almost all the sulphate reduction could be accounted for at each site (Tay estuary, 101\%; Loch Eil, $98 \%$; Loch Etive, $>100 \%$ ).
\end{abstract}

\section{INTRODUCTION}

Coastal and estuarine sediments are important sites for the mineralization of biomass produced in the photic zone (Jørgensen, 1983). Anaerobic sulphate reduction is an important process in the degradation of organic matter in these sediments, and in shallow water sediments it can be the dominant degradation process, accounting for up to $50 \%$ of organic matter degradation (Jørgensen, 1982). These data suggest that sulphate-reducing bacteria in situ are able to utilize a wide variety of organic substrates. Evidence to support this hypothesis is provided by the recent isolation of different types of sulphate-reducing bacteria able to use a

Abbreviations: AVS, acid-volatile sulphide; PVS, pyrite + sulphur; OFN, oxygen-free nitrogen; VFA, volatile fatty acids. 
variety of different substrates, such as volatile fatty acids (VFA), higher fatty acids up to 18 carbon atoms, $\mathrm{H}_{2}$, lactate, alcohols, amino acids, pyruvate, benzoate, hydroxybenzoate, phenol, phenylacetate, succinate, fumarate, malate and nicotinic acid (Bak \& Widdel, 1986; Stams et al., 1985; Widdel \& Pfennig, 1984; Imhoff-Stuckle \& Pfennig, 1983; Widdel, 1980).

Whilst there is a considerable body of data on the turnover of organic compounds within marine sediments (Ansbaek \& Blackburn, 1980; Christensen \& Blackburn, 1980; Sansone \& Martens, $1981 a, b$; Christensen \& Blackburn, 1982; Balba \& Nedwell, 1982; Banat \& Nedwell, 1983; Shaw et al., 1984; Sansone, 1986), there is relatively little information showing the direct relationship between these turnover rates and sulphate reduction. Using a combination of ${ }^{14} \mathrm{C}$ tracers and metabolic inhibitors, Banat et al. (1981) and Winfrey \& Ward (1983) demonstrated that approximately $60 \%$ of sulphate reduction was due to acetate oxidation, and suggested that $\mathrm{H}_{2}$ may account for the remainder. Sørensen et al. (1981), using molybdate (20 mM) to selectively inhibit sulphate reduction within slurries of marine sediment, measured the resultant increase in substrate concentrations and related these to the rate of sulphate reduction prior to inhibition. The results of this experiment showed that acetate, $\mathrm{H}_{2}$, propionate and butyrate accounted for $40-50,5-10,10-20$ and $10-20 \%$, respectively, of the substrates for sulphate reduction and together accounted for about $80 \%$ of the sulphate reduction. Comparable results were found by Christensen (1984), using similar sediments and techniques to Sørensen et al. (1981), but with intact sediment cores. At present it is not known how these results relate to other marine sediments, what environmental factors might influence the substrates for sulphate reduction, and what other substrates are involved in in situ sulphate reduction. In this study we have used the molybdate inhibition technique in three distinct sedimentary environments in order to address these questions.

\section{METHODS}

Study sites. Three sampling sites were used : two sea lochs on the west coast of Scotland, Lochs Etive and Eil, and Kingoodie Bay in the Tay Estuary, on the east coast of Scotland.

Loch Etive is relatively deep (maximum depth approximately $150 \mathrm{~m}$ ) and has a large catchment area $\left(1400 \mathrm{~km}^{2}\right.$; Edwards \& Edelsten, 1977), which results in the major source of sedimenting material being of terrestrial origin (Ansell, 1974).

Loch Eil is at the innermost end of Loch Linnhe and is shallower than Loch Etive, with a maximum depth of $70 \mathrm{~m}$. Unlike Loch Etive the bottom water is well connected to the Firth of Lorn, and on an annual basis there is no stagnation and the water column is well oxygenated (Pearson, 1981; Edwards et al., 1980). Loch Eil receives waste from a paper mill where it joins Loch Linnhe. The input of organic matter of terrestrial origin is much lower in this loch than in Loch Etive, while the input of planktonic carbon is much higher (Ansell, 1974; Pearson, 1982).

Kingoodie Bay is approximately $16 \mathrm{~km}$ inland from the mouth of the River Tay. At high tide the sediment is covered by about $1 \mathrm{~m}$ of water whereas at low tide the mudflats are completely exposed. This site is influenced by domestic effluent.

Sampling procedures. The sea loch sediments were sampled from the research vessel 'Seol Mara', using a Craib corer (Craib, 1965) to obtain short (approximately $15 \mathrm{~cm}$ ), undisturbed cores, or a gravity corer (Pedersen et al., 1985) to obtain longer cores (approximately $80 \mathrm{~cm}$ ). Tay estuary sediments were sampled at low tide using perspex core liners. Sediment cores were sealed at the top and bottom with rubber bungs and were returned to the laboratory, stored in ice, within a few hours of sampling.

Sediment slurries. For each site a known volume of sediment was sectioned from the anaerobic zone of several different cores, into a beaker continually flushed with oxygen-free nitrogen (OFN). This sediment was then transferred into an anaerobic cabinet (Forma Scientific), where it was thoroughly mixed. An equivalent volume of deoxygenated $50 \%(\mathrm{v} / \mathrm{v})$ seawater, containing $1 \mathrm{mM}-\mathrm{Na}_{2} \mathrm{~S}$, was mixed with the sediment, which was then passed through a $1 \mathrm{~mm}$ sieve. This slurry was then dispensed in 2 litre amounts into 2.5 litre flasks, with thorough mixing to ensure even distribution. These flasks had a sampling port at the bottom and were sealed with a rubber bung fitted with a septum for additions and gas analysis, and a stainless steel pipe to permit gassing. After the flasks were removed from the anaerobic cabinet they were flushed with OFN, leaving a slight over-pressure, and then incubated at a constant temperature with intermittent magnetic stirring. The slurries were sampled daily and the concentrations of volatile fatty acids (VFA) measured. When these were stable the rate of sulphate reduction was determined, prior to the addition of a deoxygenated solution of sodium molybdate (final concentration $20 \mathrm{mM}$ ). 
Two separate experiments were done. In experiment 1 , sediments from the following depths were used: Tay estuary 2-8 cm, Loch Eil 2-10 cm, and Loch Etive 30-40 cm. Three slurries were prepared for each site: A was a control, in B molybdate was added immediately after the stabilization period, and in $\mathrm{C}$ sodium $\left[{ }^{14} \mathrm{C}\right]$ acetate [uniformly labelled, $2 \mathrm{ml}, 10 \mu \mathrm{Ci}(370 \mathrm{kBq})$ ] was added after stabilization and molybdate added $4 \mathrm{~h}$ later. The incubation temperature for this experiment was $25^{\circ} \mathrm{C}$. In experiment 2 , sediment samples from the following depths were used: Tay estuary $2-10 \mathrm{~cm}$, Loch Eil $3-11 \mathrm{~cm}$ and Loch Etive $2-8.5 \mathrm{~cm}$. The incubation temperature was $16^{\circ} \mathrm{C}$. Only two slurries were used for each site, as treatment $\mathrm{C}$ was omitted. In both experiments samples were removed, after a period of constant stirring, using plastic syringes which had been pre-flushed with sterile OFN. For approximately $7 \mathrm{~h}$ before molybdate addition and $8 \mathrm{~h}$ after, the slurries were constantly stirred, and during this period samples for VFA analysis were collected every $30 \mathrm{~min}$. In experiment 1, samples were also removed for headspace gas analysis during this period. Pore water was obtained by centrifugation of the slurry under OFN followed by filtration through glass-fibre filters (GFF; Whatman), pre-treated by heating overnight in a muffie furnace at $350^{\circ} \mathrm{C}$. Samples for VFA analysis were stored frozen under OFN, and samples for sulphate analysis were stored in $10 \%(\mathrm{w} / \mathrm{v})$ zinc acetate $(4 \mathrm{ml}$ sample $: 1 \mathrm{ml}$ zinc acetate).

Measurement of sulphate reduction rates. In experiment 1 , sodium $\left[{ }^{35}\right.$ S] sulphate $[5 \mu \mathrm{l}$; carrier-free; $1.61 \mu \mathrm{Ci}$ $(59.6 \mathrm{kBq})]$ was injected into flask $A$ and $5 \mathrm{ml}$ subsamples were removed at 40,80 and $120 \mathrm{~min}$, for the analysis of $\left.{ }^{35} \mathrm{~S}\right]$ sulphide as described below. In experiment 2 , samples $(5 \mathrm{ml})$ were transferred to Hypo-Vials (Pierce Chemical Company), pre-flushed with OFN, crimp sealed and then [ ${ }^{35}$ S]sulphate $[4 \mu \mathrm{l} ; 1.48 \mu \mathrm{Ci}(54.8 \mathrm{kBq})] \mathrm{was}$ injected and the slurry thoroughly mixed. After $1 \mathrm{~h}$ incubation at the prevailing temperature the amount of $\left[{ }^{35} \mathrm{~S}\right]-$ sulphide produced was determined (Parkes \& Buckingham, 1986). In experiment 1 only the [ ${ }^{35}$ S]sulphide in acidvolatile sulphide (AVS) was measured, but in experiment 2, pyrite + sulphur (PVS) was also measured. The rate of sulphate reduction was calculated using the formula of Jørgensen (1978). The concentration of sulphate was determined by the method of Howarth (1978).

Analysis of VFA. In experiment 1, ion exclusion chromatography (ICE, Dionex model 14) was used, but in experiment 2, ICE and high performance liquid chromatography (HPLC, LDC) were used.

(a) VFA analysis by ICE. The samples were vacuum distilled prior to analysis as described by Parkes \& Taylor (1983) except that the concentration of $\mathrm{H}_{3} \mathrm{PO}_{4}$ was increased to $1 \mathrm{M}$ for samples containing molybdate. Calibration was done by comparison of the peak heights of samples with those obtained for external standards.

(b) VFA analysis by HPLC. Chemicals and reagents were purchased and prepared as described previously (Mueller-Harvey \& Parkes, 1987).

(i) Samples containing no molybdate. Minor modifications were made to our previous procedure (MuellerHarvey \& Parkes, 1987) to improve HPLC separations of iso- and $n$-butyrate and sensitivity and precision of detection. $\mathrm{EDC} . \mathrm{HCl} /$ pyridine reagent $(0.4 \mathrm{ml})$ was added to a pore water sample $(0.2 \mathrm{ml})$, followed immediately by $2 \mathrm{NPH} . \mathrm{HCl}$ reagent $(0.2 \mathrm{ml})$. Batches of twelve samples were derivatized at $25^{\circ} \mathrm{C}$. After addition of $\mathrm{HCl}$ $(0 \cdot 1 \mathrm{ml}, 3 \mathrm{M})$, the solution was vortex mixed for $60 \mathrm{~s}$. Chloroform $(2 \mathrm{ml})$ was added and the solution mixed for $60 \mathrm{~s}$. After phase separation, the lower, chloroform, phase was removed and transferred to a Chromacol vial. The chloroform was evaporated to dryness under a stream of nitrogen at $60^{\circ} \mathrm{C}$. The residue was dissolved in acetonitrile/water $(35 \%, v / v, 200 \mu \mathrm{l})$ and aliquots $(100 \mu \mathrm{l})$ were analysed by HPLC as described by Mueller-Harvey \& Parkes (1987), except that the column temperature was set at $30^{\circ} \mathrm{C}$.

(ii) Samples containing molybdate. Molybdate was found to interfere with VFA derivatization, but this was removed by reducing the molybdate with $\mathrm{TiCl}_{3}$ (Banat et al., 1981). Pore water samples or VFA standard solutions $(0.2 \mathrm{ml})$ with $20 \mathrm{~mm}-\mathrm{MoO}_{4}^{2-}$ were treated with aqueous $\mathrm{TiCl}_{3}(65 \mathrm{mM}, 0.2 \mathrm{ml})$ in Chromacol vials, and before derivatization they were cooled on ice, together with the reagents. Sample aliquots $(0.1 \mathrm{ml})$ were derivatized with EDC. $\mathrm{HCl} /$ pyridine $(0.4 \mathrm{ml})$ and $2 \mathrm{NPH} . \mathrm{HCl}(0.2 \mathrm{ml})$ reagents. The reaction mixture was kept at $6{ }^{\circ} \mathrm{C}$ for about $15 \mathrm{~h}$ in order to minimize side reactions. Thereafter, $\mathrm{KOH}, \mathrm{HCl}$ and chloroform were added as described above. Aliquots $(100 \mu \mathrm{l})$ were analysed by HPLC as previously described except that the column was flushed with acetonitrile (AcN) after each run. The gradient profile was: $35 \% \mathrm{AcN}(0-18 \mathrm{~min}), 35-100 \% \mathrm{AcN}(18-20 \mathrm{~min})$, $100 \%$ AcN (20-26 min), 100-35\% AcN (26-28 min), re-equilibration with $35 \%$ AcN (28-35 min).

The precision of the original method was improved with the modifications described above. Detection limits and coefficients of variation were about $0.3 \mu \mathrm{M}$ and $12 \%$ for samples without molybdate, and $1 \mu \mathrm{M}$ and $14 \%$ with molybdate. Samples containing molybdate gave lower peak heights and hence decreased sensitivity. Recoveries averaged $107 \%$ and $104 \%$ for samples without and with molybdate. Calibrations were linear for the concentrations tested.

Lactate analysis. The concentration of lactate was determined enzymically (Boehringer-Mannheim).

Amino acid analysis. An HPLC derivatization procedure using $o$-phthalaldehyde coupled with fluorometric detection (Lindroth \& Mopper 1979; Stanley et al., 1987) was used for the determination of individual amino acids. Calibration was by internal standard ( $\varepsilon$-amino- $n$-caproic acid) and peak areas were measured by an integrator (Hewlett Packard 1360).

Gas analysis. Headspace gases were sampled through the septum in the top of the flasks and were analysed on a Pye Unicam model 104 gas chromatograph, with a katharometer detector. Gases $\left(\mathrm{H}_{2}, \mathrm{CH}_{4}, \mathrm{CO}_{2}\right)$ were separated 
with nitrogen as the carrier gas $\left(35 \mathrm{ml} \mathrm{min}^{-1}\right)$ on a glass column packed wth Porapak Q (Supelco). The column and detector temperatures were $50^{\circ} \mathrm{C}$ and $100^{\circ} \mathrm{C}$, respectively.

Mineralization of $\left[{ }^{14} \mathrm{C}\right.$ acetate. After the stabilization period, $2 \mathrm{ml}$ sodium $\left[{ }^{14} \mathrm{C}\right]$ acetate $(10 \mu \mathrm{Ci} ; 370 \mathrm{kBq})$ was added to flask C. Every $30 \mathrm{~min}, 5 \mathrm{ml}$ of slurry was removed and placed into a $100 \mathrm{ml}$ Hypo Vial and sealed. The vial was then connected to a sparging system linked to two scintillation vials containing a $\mathrm{CO}_{2}$-absorbing scintillant. The sample was acidified and $\mathrm{CO}_{2}$ trapped as described by Parkes et al. (1984). Residual $\left[{ }^{14} \mathrm{C}\right]$ acetate was measured after filtering through a GFF filter. All radioactive measurements were obtained using a scintillation counter (LKB), with quench correction by external standard.

\section{RESULTS}

\section{Experiment 1}

The time required for the VFA to stabilize was $6 \mathrm{~d}$ for the Tay estuary and Loch Eil and $7 \mathrm{~d}$ for Loch Etive. During this period there was a small decrease in sulphate concentrations and a comparable increase in sulphide concentrations. During stabilization the acetate concentrations increased markedly at about day 3 and then decreased to near the original concentrations (Loch Eil and Loch Etive sediments) or higher concentrations (Tay estuary sediments). In contrast, propionate concentrations were relatively stable, although much lower than those of acetate (approximately 1:0.1 acetate :propionate, Table 2). On the addition of $20 \mathrm{~mm}$-molybdate (flask B) there was an immediate, linear, and rapid increase in acetate (all sites), lactate and $\mathrm{CH}_{4}$ (Tay estuary), $\mathrm{H}_{2}$ (Lochs Eil and Etive), propionate (Tay estuary and Loch Eil) and certain amino acids (Tay estuary and Loch Eil) (Figs 1 and 2; Table 1). Throughout this period the concentration of these compounds in the flasks without molybdate (A and C) remained constant (data not shown). When molybdate was added to flask $C$ this resulted in an immediate and similar increase in substrate concentrations to those observed for flask B (Fig. 1). In addition, $\left[{ }^{14} \mathrm{C}\right]$ acetate mineralization in this flask ceased (Fig. 3).

The rate of increase in substrate concentrations after molybdate addition was calculated by linear regression analysis (Table 1). The relationship between the three sites in terms of the rate of substrate increase was the same as that for rates of sulphate reduction: Tay estuary $\gg$ Loch Eil $>$ Loch Etive. The rates of substrate increase were converted to equivalent rates of sulphate reduction using the appropriate stoichiometries (Sørensen et al., 1981; Widdel, 1980; Thauer et al., 1977), and assuming complete degradation to $\mathrm{CO}_{2}$ (Table 1).

The increase in methane concentration after addition of molybdate to the Tay slurries was relatively minor (similar rates to $\mathrm{H}_{2}$, Table 1) and could have been derived from either acetate or $\mathrm{H}_{2}$. There was a small amount of residual ${ }^{14} \mathrm{CO}_{2}$ production after molybdate addition (Fig. 3), which could have been due to methanogenesis from uniformly labelled $\left[{ }^{14} \mathrm{C}\right]$ acetate producing both ${ }^{14} \mathrm{CO}_{2}$ and ${ }^{14} \mathrm{CH}_{4}$, but this activity was not associated with an equivalent decrease in $\left[{ }^{14} \mathrm{C}\right]-$ acetate (Fig. 3). Similarly, the absence of $\mathrm{H}_{2}$ accumulation in these slurries may or may not indicate methanogenesis from $\mathrm{H}_{2}$. Therefore as the substrates for sulphate reduction represented by the increase in methanogenesis could not be clearly identified, and the increase in methanogenesis was relatively minor, these data were not used in the calculation of substrates for sulphate reduction (Table 1).

Linear increases in amino acids were observed only in the Tay estuary and Loch Eil slurries (Fig. $2 a, b$ ). Of 21 individual amino acids which could be measured there was a linear increase in nine. The most important amino acids for both sites were serine and glutamate, whilst in the Loch Eil samples arginine was also important (Table 1). In addition phenylalanine accumulated only in the Loch Eil slurries, whilst iso-leucine only increased in the Tay estuary slurries. In the Loch Etive slurries there was either no change in the concentration of amino acids compared to the control (14 amino acids), or the small increase was not significant compared to the general variability of the data (six amino acids).

\section{Experiment 2}

After an $8 \mathrm{~d}$ stabilization period, the VFA concentrations in the sediment slurries were similar to those in the original pore waters. The acetate concentration was much higher than that of the other VFA, and at the end of the stabilization period the acetate : propionate ratio was the same 
Table 1. Substrates for sulphate reduction in Loch Etive, Loch Eil and the Tay Estuary, determined by the addition of $20 \mathrm{mM}-$ molybdate to sediment slurries and assuming complete substrate oxidation

\begin{tabular}{|c|c|c|c|c|c|c|c|c|c|c|}
\hline \multirow{3}{*}{$\begin{array}{l}\text { Sampling } \\
\text { site }\end{array}$} & \multicolumn{6}{|c|}{ Experiment 1} & \multicolumn{4}{|c|}{ Experiment 2} \\
\hline & \multicolumn{3}{|c|}{$\begin{array}{l}\text { Accumulation rate } \\
\text { in the presence of } \\
\mathrm{MoO}_{4}^{2-}(\mu \mathrm{mol} \mathrm{h-1)}\end{array}$} & \multicolumn{3}{|c|}{$\begin{array}{l}\text { Percentage of } \\
\text { sulphate reduction } \\
\text { (AVS) accounted for } \\
\text { by the various } \\
\text { substrates }\end{array}$} & \multicolumn{2}{|c|}{$\begin{array}{l}\text { Accumulation rate } \\
\text { in the presence of } \\
\mathrm{MoO}_{4}^{2-}\left(\mu \mathrm{mol} \mathrm{h} \mathrm{h}^{-1}\right)\end{array}$} & \multicolumn{2}{|c|}{$\begin{array}{l}\text { Percentage of } \\
\text { sulphate reduction } \\
\text { (AVS + PVS) } \\
\text { accounted for by the } \\
\text { various substrates }\end{array}$} \\
\hline & Etive & Eil & Tay & Etive & Eil & Tay & Eil & Tay & Eil & Tay \\
\hline \multicolumn{11}{|l|}{ bstrate } \\
\hline tate & 0.095 & 0.312 & 7.95 & $>100$ & $63 \cdot 80$ & $35 \cdot 52$ & $5 \cdot 24$ & $11 \cdot 33$ & $48 \cdot 10$ & 42.68 \\
\hline t & - & - & $6 \cdot 48$ & - & - & 43.40 & & & & \\
\hline pionate & - & 0.035 & 0.77 & - & $12 \cdot 53$ & 6.02 & 0.6 & 1.42 & 9.55 & $9 \cdot 38$ \\
\hline & 0.001 & 0.002 & - & 1.89 & $0 \cdot 10$ & - & & & & \\
\hline nine & - & 0.019 & - & - & 2.91 & - & & & & \\
\hline & - & 0.015 & 0.228 & - & $2 \cdot 30$ & 0.77 & & & & \\
\hline tamate & - & $0 \cdot 011$ & 0.154 & - & 1.69 & 0.52 & & & & \\
\hline ine & - & 0.005 & $0 \cdot 104$ & - & 0.77 & 0.35 & & & & \\
\hline artate & - & $0 \cdot 004$ & 0.075 & - & 0.61 & $0 \cdot 25$ & & & & \\
\hline ne & - & $0 \cdot 002$ & 0.065 & - & $0 \cdot 31$ & $0 \cdot 22$ & & & & \\
\hline & - & 0.002 & 0.054 & - & 0.31 & $0 \cdot 18$ & & & & \\
\hline cine & - & - & 0.027 & - & - & 0.09 & & & & \\
\hline enylalanine & - & 0.002 & - & - & 0.31 & - & & & & \\
\hline utyrate & & & & & & & $0 \cdot 11$ & 0.39 & $2 \cdot 55$ & 3.65 \\
\hline -Butyrate & & & & & & & $0 \cdot 12$ & 0.37 & $2 \cdot 68$ & 3.45 \\
\hline -Valerate & & & & & & & $0 \cdot 11$ & 0.30 & $3 \cdot 28$ & 3.72 \\
\hline Methylbutyrate & & & & & & & $0 \cdot 11$ & 0.22 & $3 \cdot 16$ & $2 \cdot 64$ \\
\hline Valerate & & & & & & & 0.03 & 0.09 & 0.93 & $1 \cdot 13$ \\
\hline & \multicolumn{3}{|c|}{ Total } & $>100$ & 85.64 & $87 \cdot 32$ & & Total & $70 \cdot 25$ & 66.65 \\
\hline & \multicolumn{3}{|c|}{$\begin{array}{l}\text { Sulphate reduction } \\
\text { rate }\left(\mu \mathrm{mol} \mathrm{h}^{-1}\right) \ldots\end{array}$} & 0.05 & 0.49 & $22 \cdot 38$ & \multicolumn{2}{|c|}{$\begin{array}{l}\text { Sulphate reduction } \\
\text { rate }\left(\mu \mathrm{mol} \mathrm{h}^{-1}\right) \ldots\end{array}$} & $10 \cdot 9$ & $26 \cdot 5$ \\
\hline
\end{tabular}

Grand total (expt 1 + VFA from expt 2, except acetate and propionate) $\ldots>100 \quad 98.24 \quad 101.91$

-, Not detected; a space indicates 'not determined'.

Table 2. Concentrations of substrates in Loch Etive, Loch Eil and Tay Estuary sediment slurries after the stabilization period

\begin{tabular}{|c|c|c|c|c|}
\hline \multirow[b]{2}{*}{ Expt } & \multirow[b]{2}{*}{ Substrate } & \multicolumn{3}{|c|}{ Substrate concn $(\mu \mathrm{M})$} \\
\hline & & Etive & Eil & Tay \\
\hline \multirow[t]{4}{*}{1} & Lactate & $3 \cdot 5$ & $11 \cdot 0$ & $24 \cdot 0$ \\
\hline & Acetate & $14 \cdot 3$ & $18 \cdot 4$ & $35 \cdot 5$ \\
\hline & Propionate & $1 \cdot 3$ & 1.7 & $2 \cdot 4$ \\
\hline & Total amino acids & 0.28 & 0.44 & $6 \cdot 1$ \\
\hline \multirow[t]{7}{*}{2} & Acetate & 4.0 & $12 \cdot 3$ & $10 \cdot 8$ \\
\hline & Propionate & - & 0.8 & 0.7 \\
\hline & iso-Butyrate & - & 0.02 & 0.0 \\
\hline & n-Butyrate & - & 0.47 & $0 \cdot 21$ \\
\hline & 2-Methyl butyrate & - & 0.14 & 0.05 \\
\hline & iso-Valerate & - & $0 \cdot 12$ & 0.05 \\
\hline & $n$-Valerate & - & 0.33 & $0 \cdot 20$ \\
\hline
\end{tabular}

-, Not detected. 


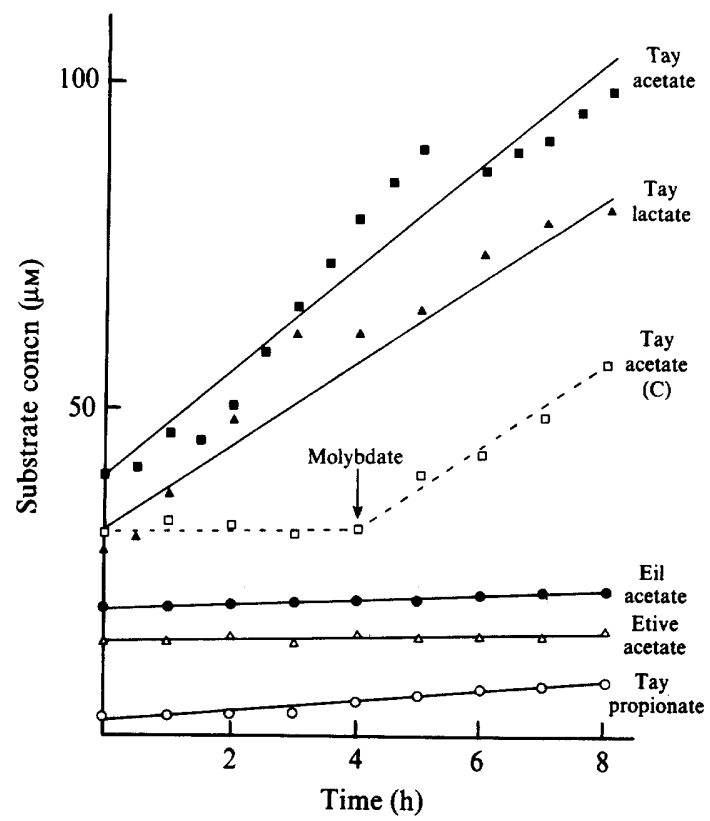

Fig. 1. Accumulation of substrates for sulphate-reducing bacteria due to addition of molybdate $(20 \mathrm{mM})$ to Tay, Etive and Eil sediment slurries. Experiment 1 (data are from flask B, except where labelled differently).
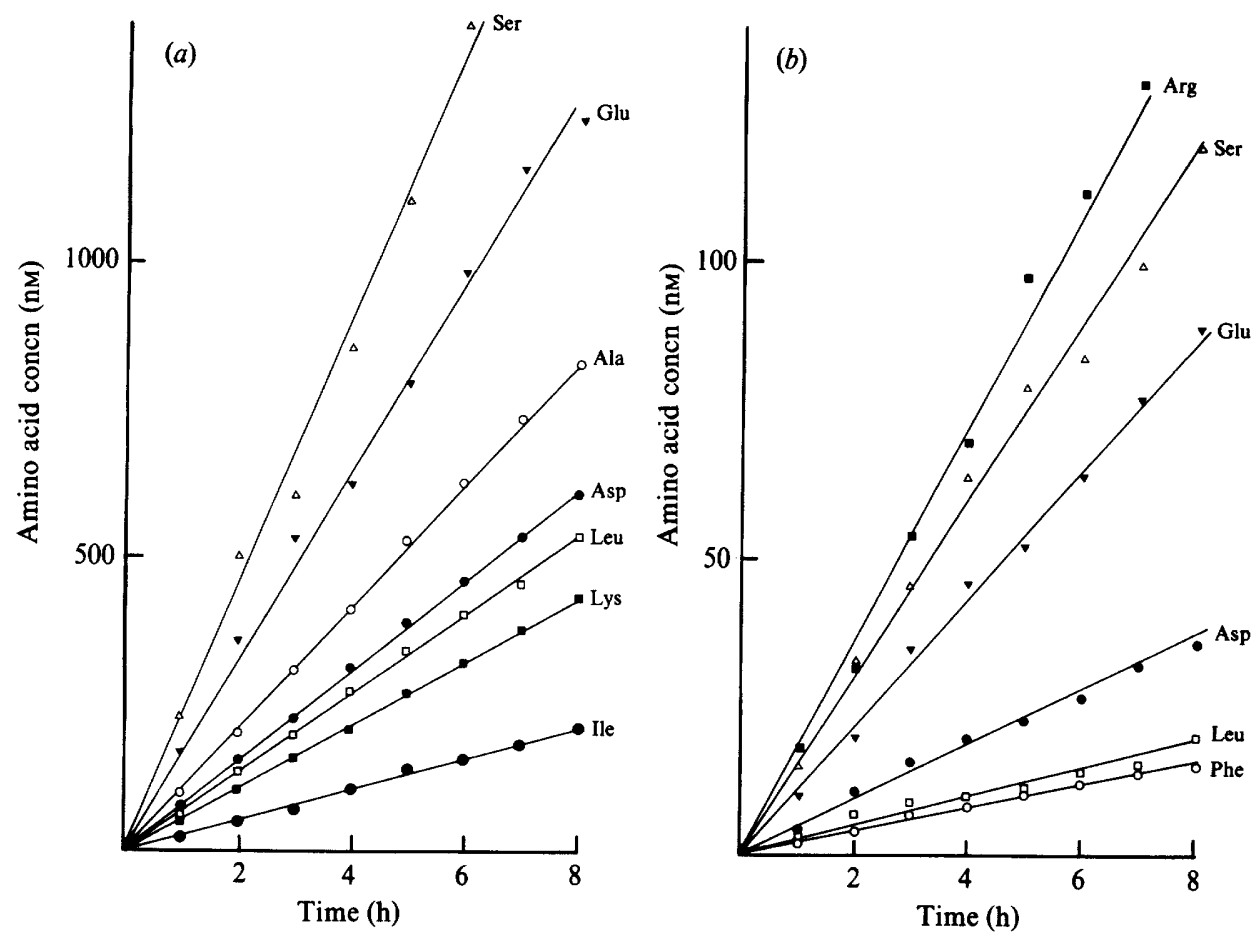

Fig. 2. Accumulation of amino acids due to inhibition of sulphate reduction by addition of molybdate $(20 \mathrm{mM})$ to sediment slurries from the Tay estuary $(a)$ and Loch Eil $(b)$. Experiment 1, flask B. 
Substrates for sulphate-reducing bacteria

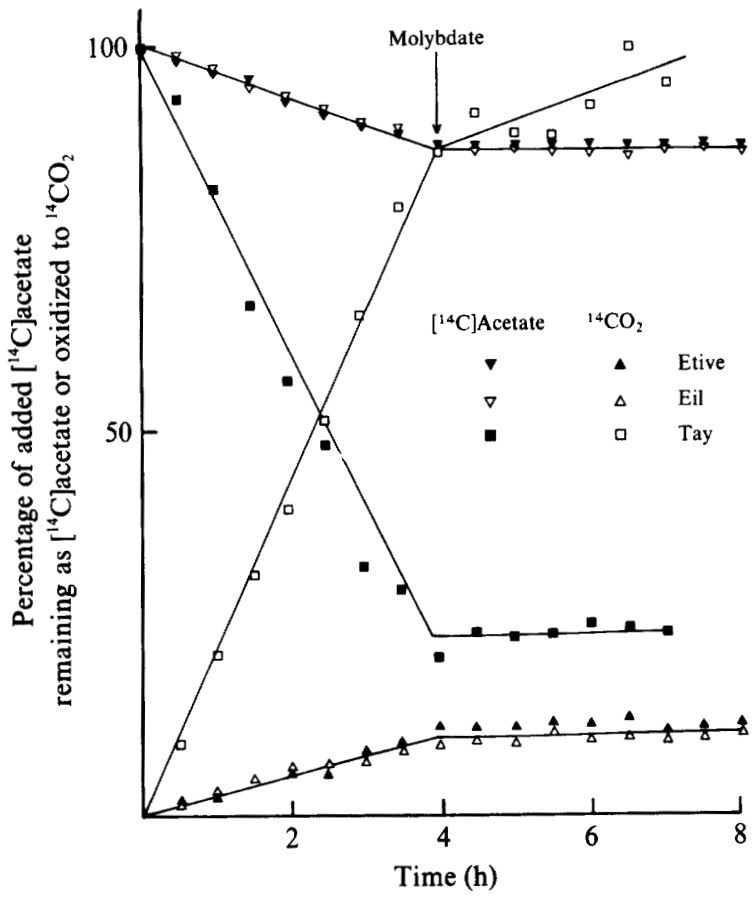

Fig. 3. Effect of the inhibition of sulphate reduction by addition of molybdate $(20 \mathrm{~mm})$ on the mineralization of $\left[\mathrm{U}^{14} \mathrm{C}\right]$ acetate in Loch Etive, Loch Eil and Tay estuary sediment slurries. Experiment 1, flask C.

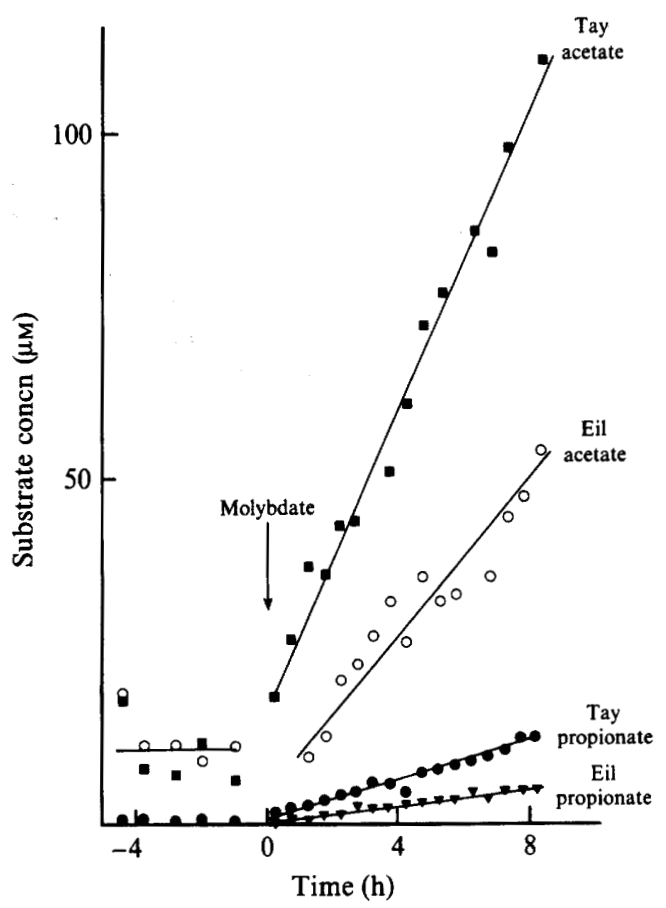

Fig. 4. Accumulation of acetate and propionate due to inhibition of sulphate reduction by addition of molybdate (20 mM) to Loch Eil and Tay estuary sediment slurries. Experiment 2, flask B. 


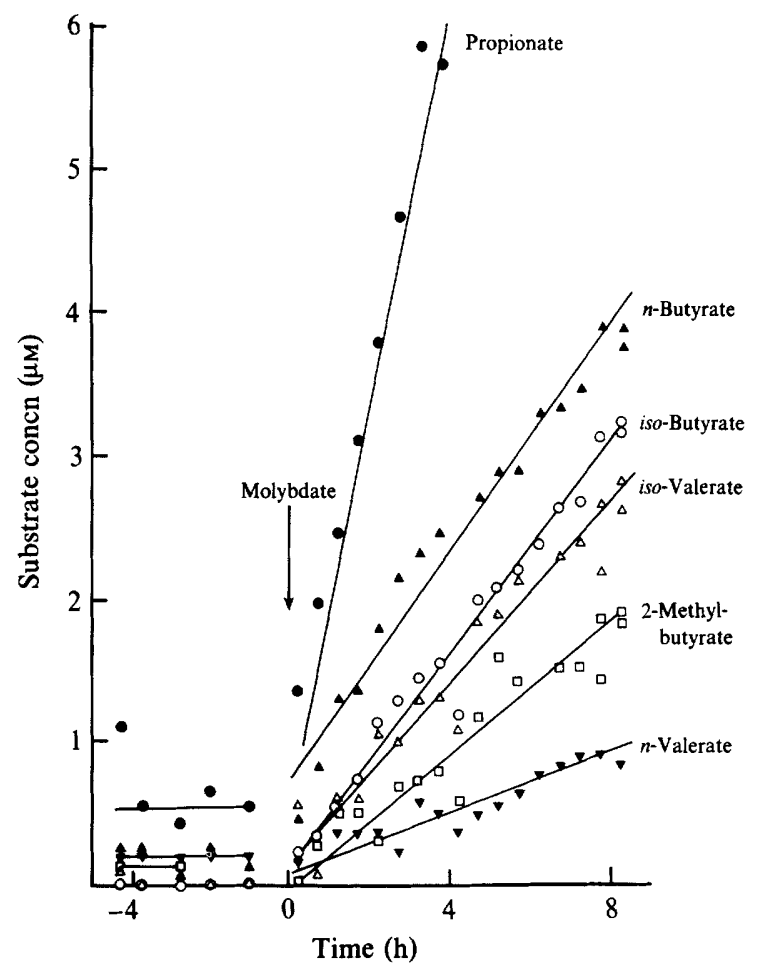

Fig. 5. Accumulation of volatile fatty acids due to inhibition of sulphate reduction by addition of molybdate $(20 \mathrm{~mm})$ to Tay estuary sediment slurries. Experiment 2, flask B.

as in experiment $1(1: 0 \cdot 1)$. In both Tay estuary and Loch Eil slurries, molybdate addition resulted in an immediate and linear increase in all the VFA that were measured (Figs 4 and 5; Table 1). Consistent with the previous results, both the rate of substrate increase and rates of sulphate reduction were much higher in the Tay estuary than in the Loch Eil slurries (Table 1). Acetate was the major substrate for sulphate reduction, accounting for almost $50 \%$ of the total sulphate reduced. There was good agreement between the rate of increase in acetate due to molybdate addition determined using either ICE or HPLC analysis.

As in experiment 1, the rates of sulphate reduction for Loch Etive slurries were much lower than in the other slurries, but in experiment 2 no linear increase in substrates could be detected after molybdate addition. This was probably the result of problems with the analytical detection limits associated with the much lower substrate concentrations present in the repeat experiment (e.g. acetate concentrations: expt $1,14 \mu \mathrm{M}$; expt $2,4 \mu \mathrm{M})$. The contribution of $\left[{ }^{35}\right.$ S]sulphide in PVS to the total products of sulphate reduction was relatively small: $6 \%$ for Tay estuary and $18 \%$ for Loch Eil slurries.

Although there was broad agreement between the results of the two experiments (Table 1), there were some differences in the sea loch sites; this was probably a reflection of seasonal changes in the quantity and quality of organic inputs to the sediment. In addition, the different incubation temperatures (expt $1,25^{\circ} \mathrm{C}$; expt $2,16^{\circ} \mathrm{C}$ ) may have contributed to differences observed between the two experiments.

\section{DISCUSSION}

It is widely accepted that acetate and hydrogen are important substrates for sulphate reduction in intertidal and marine sediments (Taylor \& Parkes, 1985; Christensen, 1984; King, 1984; Winfrey \& Ward, 1983; Balba \& Nedwell, 1982; Banat et al., 1981; Sørensen et al., 1981). 
Acetate is considered the principal substrate, accounting for up to $70 \%$ of the total sulphate reduced in marine sediments. However, other potentially important substrates for in situ sulphate reduction have not been fully investigated; these include lactate (Postgate, 1984), amino acids (Stams et al., 1985) and the less commonly measured VFA such as iso- and $n$ valerate, and 2-methylbutyrate (Mueller-Harvey \& Parkes, 1987).

The results presented in this paper show that a range of substrates can be used by sulphatereducing bacteria within marine sediments but that the importance of individual substrates varies between different environments. These results are based on the use of molybdate to specifically inhibit sulphate reduction and measuring the resultant accumulation of organic substrates. Molybdate inhibition has been widely used within sediments, and for marine systems it seems to be a specific inhibitor (Jacobson et al., 1987; Banat et al., 1983; Sørensen et al., 1981) and does not significantly affect other processes such as fermentation reactions supplying substrates for sulphate reduction and methanogenesis. Inhibition of these reactions by molybdate would mean that substrate increase due to molybdate addition would not be an accurate measure of the substrates for sulphate reduction. The specific action of molybdate in our experiments is demonstrated by several different observations. (1) The linear increases in substrate concentrations after molybdate addition (Figs 1, 2, 4 and 5) indicate that molybdate did not alter the fermentation pathways, over the $8 \mathrm{~h}$ experimental period. (2) The total rates of substrate accumulation, on the whole, closely matched the measured rates of sulphate reduction (Table 1). (3) The acetate:propionate ratio, which is sensitive to $\mathbf{H}_{2}$ perturbation of fermentation reactions (Sørensen et al., 1981; Kasper \& Wuhrmann, 1978) was the same $(1: 0 \cdot 1)$ before and after molybdate addition. (4) Inhibition of methanogenesis was unlikely, as molybdate addition actually stimulated methanogenesis in the Tay estuary slurries. There is also the possibility that sulphate-reducing bacteria are tightly coupled via $\mathrm{H}_{2}$ to acetogens (e.g. McInerney et al., 1979) and substrate accumulation due to molybdate addition may result from the inhibition of this syntrophic association. However, the very rapid substrate accumulation due to molybdate addition in these experiments (Figs 4 and 5), coupled with the very low accumulation of $\mathrm{H}_{2}$ (Table 1), would indicate that substrate accumulation was due to direct inhibition of sulphate-reducing bacteria. Hence the results presented in Table 1 are an accurate measurement of the substrates for sulphate reduction at each site.

Experiment 1. Acetate was a major substrate for sulphate reduction in sediment slurries from all three sites, but the actual contribution of acetate to sulphate reduction varied from $100 \%$ in the Loch Etive to $35 \%$ in the Tay estuary samples. The immediate inhibition of $\left[{ }^{14} \mathrm{C}\right]$ acetate turnover upon molybdate addition (Fig. 3) provides further support for the major role of acetate in sulphate reduction. The lesser contribution of acetate as a substrate for sulphate reduction in the Tay estuary samples, compared to those from Lochs Eil and Etive (Table 1), was balanced by an increase in the importance of lactate and propionate: these accounted for $43 \%$ and $6 \%$, respectively, of sulphate reduction (assuming complete oxidation). Lactate was only important in the Tay estuary samples, which had the highest concentrations of this compound (Table 2). When lactate is added to marine sediment slurries at high concentrations it is usually incompletely oxidized to acetate and propionate (Parkes \& Taylor, 1985; Laanbroek \& Pfennig, 1980). Incomplete oxidation would decrease the contribution of lactate to sulphate reduction to $15 \%$. However, sulphate-reducing bacteria can completely oxidize lactate (Widdel, 1980), and this may be the dominant degradation pathway at the low lactate concentrations in situ. Lactate has been shown to be an important substrate for sulphate reduction in freshwater sediments (Hordijk \& Cappenberg, 1983; Cappenberg \& Prins, 1974), and radiotracer studies with lactate have shown that this compound is oxidized in marine sediments (Sansone, 1986), but until now there has been little direct evidence demonstrating its importance for sulphate reduction in marine or estuarine sediments at in situ lactate concentrations.

The amino acids most important for sulphate reduction in the Loch Eil and the Tay estuary samples (serine and glutamate, and in addition for Loch Eil, arginine; Table 1), are common amino acids in marine environments (Stanley et al., 1987). Although the rate of increase in amino acids was greater in the Tay estuary samples, the percentage of sulphate reduction 
accounted for by these substrates was higher in the Loch Eil samples ( $9 \%$ compared with $2 \%$ ). Laboratory cultures of sulphate reducing bacteria have been shown to utilize amino acids (Skyring et al., 1977; Stams et al., 1985), and Smith \& Klug (1981) showed that sulphate reduction was involved in the mineralization of a mixture of ${ }^{14} \mathrm{C}$-labelled amino acids added to freshwater sediments. But to our knowledge this is the first report of utilization of specific amino acids by natural populations of marine sulphate-reducing bacteria at in situ amino acid concentrations. The percentage of sulphate reduction due to amino acid degradation was small compared to that due to acetate oxidation; however, amino acids may provide an important source of nitrogen for sulphate-reducing bacteria.

Experiment 2. The results from this experiment were in broad agreement with those of experiment 1 . Sulphate reduction rates in the Loch Eil slurry were, however, higher than in the initial experiment and more similar to the rates in the Tay estuary samples. In addition, acetate and propionate represented an equivalent proportion of sulphate reduction at both sites (Table 1). Analysis of VFA other than acetate and propionate showed that these compounds are also substrates for sulphate-reducing bacteria (Table 1, Fig. 5). In both Loch Eil and the Tay estuary, $n$ - and iso-butyrate, iso-valerate and 2-methylbutyrate were of approximately equal importance as substrates for sulphate reduction at each site, with $n$-valerate being less important. Together these VFA accounted for a slightly greater amount of sulphate reduction in the Tay estuary than in the Loch Eil samples. This is the first time that 2-methylbutyrate has been shown to be a substrate for natural populations of sulphate reducers, although its presence in anoxic marine pore waters implied that it was involved in anaerobic metabolism (Mueller-Harvey \& Parkes, 1987), and Widdel (1980) showed that it could be completely degraded to $\mathrm{CO}_{2}$ by some sulphatereducing bacteria. This compound is a specific anaerobic degradation product of isoleucine (Barker, 1981) and results from experiment 1 showed that this amino acid was involved in sulphate reduction (Fig. 2).

General remarks. In these two experiments, 18 individual substrates were shown to be involved in sulphate reduction at the different sites. This significantly extends the substrates known to be used by natural populations of sulphate-reducing bacteria, and demonstrates that acetate turnover cannot be used as an overall measure of organic matter degradation (Christensen \& Blackburn, 1982; Sansone, 1986). This result is consistent with the recent isolation of a number of different sulphate-reducing bacteria able to use a wide variety of substrates. Assuming complete oxidation of the substrates and combining the data from experiments 1 and 2, almost all the sulphate reduced can be accounted for by the substrates found to increase following molybdate addition (Table 1). The assumption that complete substrate oxidation by sulphate-reducing bacteria was occurring seems valid, as the rates of sulphate reduction thus calculated were very close to the measured rate of sulphate reduction (Table 1). In addition, Sansone (1986) concluded that the main source of acetate within marine sediments was carbohydrates or other complex organic compounds rather than VFA or other metabolic intermediates. Previous work by Sørensen et al. (1981), assuming complete substrate oxidation, only accounted for approximately $80 \%$ of the total sulphate reduced in marine sediments. If incomplete oxidation of substrates is assumed, this considerably diminishes the importance of substrates other than acetate and reduces the overall percentage of sulphate reduction accounted for in the Loch Eil $(83 \%)$ and the Tay estuary $(63 \%)$ samples. The results for Loch Etive remain unchanged, as acetate is virtually the sole substrate and cannot be incompletely oxidized.

The increase in acetate due to molybdate addition in Loch Etive slurries was considerably greater than the measured rate of sulphate reduction (Table 1). This may have been due to an underestimate of sulphate reduction in experiment 1 , as only $\left[{ }^{35}\right.$ S $]$ sulphide incorporated in AVS was measured. Pyrite and sulphur (PVS) are important products of sulphate reduction in some sediments (Howarth \& Jørgensen, 1984; Howarth \& Giblin, 1983; Howarth \& Teal, 1979). In Loch Etive at the sediment depth used in experiment $1(30-40 \mathrm{~cm})$, over $60 \%$ of the sulphate reduced was present as PVS (Parkes \& Buckingham, 1986), and this would account for most of 
the discrepancy observed between acetate accumulation and rates of sulphate reduction. In experiment 2, PVS accounted for $6 \%$ and $18 \%$ of the total sulphate reduction in the Tay estuary and Loch Eil slurries, respectively, and this would have contributed to the lower percentage of sulphate reduction accounted for at these sites compared to experiment 1 (Table 1).

Christensen (1984) demonstrated that molybdate inhibition within slurries gave similar results to the use of molybdate within intact cores, and therefore it seems reasonable to assume that the substrates for sulphate reduction determined in our slurry experiments are also a close approximation to those within undisturbed sediments.

In the results of both experiments there appears to be a relationship between the rate of sulphate reduction and the substrates used for this process (Table 1). In the Tay estuary slurries, which have high rates of sulphate reduction, acetate is not the dominant substrate and other more reduced compounds (lactate and propionate) play a significant role. In contrast, in the Loch Etive slurries, with much lower rates of sulphate reduction, acetate is virtually the sole substrate for sulphate reduction (Table 1). The Loch Eil slurries are intermediate between these extremes. The most active sites also have the highest concentrations of organic intermediates (Table 2), the sedimenting material is more available to microbial degradation (Parkes \& Buckingham, 1986), and thus it is likely that a more heterogeneous microbial population is present to produce a variety of substrates for sulphate reduction. More work needs to be done to confirm whether this relationship between sulphate reduction rates and the substrates for this process is applicable to other anoxic sediments.

This work was supported by the Natural Environmental Research Council (NERC), and G. Gibson was in receipt of a NERC CASE studentship. We wish to thank Drs B. Cragg and J. Mauchline for critically reading the manuscript.

\section{REFERENCES}

Ansbaek, J. \& Blackburn, T. H. (1980). A method for the analysis of acetate turnover in a coastal marine sediment. Microbial Ecology 5, 253-264.

ANSELL, A. D. (1974). Sedimentation of organic detritus in Lochs Etive and Creran, Argyll, Scotland. Marine Biology 27, 263-273.

BAK, F. \& WIDDEL, F. (1986). Anaerobic degradation of phenol and phenol derivatives by Desulfobacterium phenolicum sp. nov. Archives of Microbiology 146, $177-180$.

BalbA, M. T. \& Nedwell, D. B. (1982). Microbial metabolism of acetate, propionate and butyrate in anoxic sediment from the Colne Point salt marsh Essex, UK. Journal of General Microbiology 128, 1415-1422.

Banat, I. M. \& NeDWell, D. B. (1983). Mechanisms of turnover of $\mathrm{C}_{2}-\mathrm{C}_{4}$ fatty acids in high sulphate and low sulphate anaerobic sediments. FEMS Microbiology Letters 17, 107-110.

Banat, I. M., Lindström, E. B., Nedwell, D. B. \& BALBA, M. T. (1981). Evidence for the existence of two distinct functional groups of sulphate-reducing bacteria in salt marsh sediment. Applied and Environmental Microbiology 42, 985-992.

Banat, I. M., NedWell, D. B. \& Balba, M. T. (1983). Stimulation of methanogenesis by slurries of salt marsh sediment after the addition of molybdate to inhibit sulphate-reducing bacteria. Journal of General Microbiology 129, 123-129.

BARKER, H. A. (1981). Amino acid degradation by anaerobic bacteria. Annual Review of Biochemistry 50, 23-40.

Cappenberg, T. E. \& Prins, R. A. (1974). Interrela- tions between sulfate-reducing and methane-producing bacteria in bottom deposits of a fresh-water lake. III. Experiments with ${ }^{14} \mathrm{C}$-labelled substrates. Antonie van Leeuwenhoek 40, 457-469.

CraIB, J. S. (1965). A sampler for taking short undisturbed marine cores. Journal du Conseil, Conseil Permanent International pour l'Exploration de la Mer 30, 34-39.

Christensen, D. (1984). Determination of substrates oxidised by sulfate reduction in intact cores of marine sediments. Limnology and Oceanography 29, 189-192.

Christensen, D. \& Blackburn, T. H. (1980). Turnover of tracer $\left({ }^{14} \mathrm{C},{ }^{3} \mathrm{H}\right.$-labelled) alanine in inshore marine sediments. Marine Biology 58, 97-103.

Christensen, D. \& Blackburn, T. H. (1982). Turnover of ${ }^{14} \mathrm{C}$-labelled acetate in marine sediments. Marine Biology 71, 113-119.

EdWARds, A. \& Edelsten, D. J. (1977). Deep water renewal of Loch Etive: a three basin Scottish fjord. Estuarine, Coastal and Marine Science 5, 575595.

EdWards, A., Edelsten, D. J., Saunders, M. A. \& StANLEY, S. O. (1980). Renewal and entrainment in Loch Eil: a periodically ventilated Scottish fjord. In Fjord Oceanography, pp. 523-530. Edited by H. J. Freeland, D. M. Farmer \& C. D. Levings. New York \& London: Plenum Press.

HordiJK, K. A. \& CAPpenberg, T. E. (1983). Quantitative high-pressure liquid chromatographyfluorescence determination of some important lower fatty acids in lake sediments. Applied and Environmental Microbiology 46, 361-369. 
HowARTH, R. W. (1978). A rapid and precise method for determining sulfate in seawater, estuarine waters and sediment. Limnology and Oceanography 25, 1066-1069.

Howarth, R. W. \& Giblin, A. (1983). Sulfate reduction in the salt marshes at Sapelo Island, Georgia. Limnology and Oceanography 28, 70-82.

Howarth, R. W. \& JøRGENSEN, B. B. (1984). Formation of ${ }^{35} \mathrm{~S}$-labelled elemental sulfur and pyrite in coastal marine sediments (Limfjorden and Kysing Fjord, Denmark) during short term ${ }^{35} \mathrm{SO}_{4}^{2-}$ reduction measurements. Geochimica et cosmochimica acta 48, 1807-1818.

Howarth, R. W. \& Teal, J. M. (1979). Sulfate reduction in a New England salt marsh. Limnology and Oceanography 24, 999-1013.

ImHoff-StUCKLe, D. \& PFENNIG, N. (1983). Isolation and characterization of a nicotinic acid-degrading sulfate-reducing bacterium, Desulfococcus niacini sp. nov. Archives of Microbiology 136, 194-198.

JaCobson, M. E., Mackin, J. E. \& CAPONe, D. G. (1987). Ammonium production in sediments inhibited with molybdate: implications for the sources of ammonium in anoxic marine sediments. Applied and Environmental Microbiology 53, 2435-2439.

JøRGENSEN, B. B. (1978). A comparison of methods for the quantification of bacterial sulfate reduction in coastal marine sediments. I. Measurement with radiotracer techniques. Geomicrobiology Journal 1, 11-27.

JøRGENSEN, B. B. (1982). Mineralization of organic matter in the sea-bed - the role of sulphatereduction. Nature, London 296, 643-645.

Jørgensen, B. B. (1983). Processes at the sedimentwater interface. In The Major Biogeochemical Cycles and their Interactions, pp. 477-515. Edited by B. Bolin \& R. B. Cook. Chichester: Scope Wiley.

KASPER, H. \& WuHrmanN, K. (1978). Kinetic parameters and relative turnovers of some important catabolic reactions in digesting sludge, Applied and Environmental Microbiology 36, 1-7.

KING, G. M. (1984). Metabolism of trimethylamine, choline and glycine betaine by sulfate-reducing and methanogenic bacteria in marine sediments. Applied and Environmental Microbiology 48, 719-725.

LAANBroek, H. J. \& PfenNig, N. (1981). Oxidation of short-chain fatty acids by sulphate-reducing bacteria in freshwater and marine sediments. Archives of Microbiology 128, 330-335.

LINDROTH, P. \& MOPPER, K. (1979). High performance liquid chromatography determination of subpicomole amounts of amino acids by precolumn fluorescence derivatization with $o$-phthaldialdehyde. Analytical Chemistry 51, 1667-1674.

Mcinerney, M. J., Bryant, M. P. \& Pfennig, N. (1979). Anaerobic bacterium that degrades fatty acids in syntrophic association with methanogens. Archives of Microbiology 122, 129-135.

Mueller-Harvey, I. \& Parkes, R. J. (1987). Measurement of volatile fatty acids in pore water from marine sediments by HPLC. Estuarine, Coastal and Shelf Science 25, 567-579.

OREMLAND, R. S. \& TAYLOR, B. F. (1978). Sulphate reduction and methanogenesis in marine sediments. Geochimica et cosmochimica Acta 42, 209-214.
Parkes, R. J. \& Buckingham, W. J. (1986). The flow of organic carbon through aerobic respiration and sulfate reduction in inshore marine sediments. Proceedings of the Fourth International Symposium on Microbial Ecology, pp. 617-624.

PARkes, R. J. \& TAYLOR, J. (1983). Analysis of volatile fatty acids by ion-exclusion chromatography, with special reference to marine pore water. Marine Biology 77, 113-118.

PARKeS, R. J. \& TAYLOR, J. (1985). Characterization of microbial populations in marine sediments. Journal of Applied Bacteriology Symposium Supplement 59, $155 \mathrm{~S}-173 \mathrm{~S}$.

Parkes, R. J., TAYloR, J. \& JøRk-Ramberg, D. (1984). Demonstration, using Desulfobacter sp., of two pools of acetate with different biological availabilities in marine pore water. Marine Biology 83, 271-276.

Pearson, T. H. (1981). The Loch Eil project introduction and rationale. Journal of Experimental Marine Biology and Ecology 55, 93-102.

Pearson, T. H. (1982). The Loch Eil project: assessment and synthesis, with a discussion of certain biological questions arising from a study of the organic pollution of sediments. Journal of Experimental Marine Biology and Ecology 57, 93124.

Pedersen, T. F., Malcolm, S. J. \& Sholkovitz, E. R. (1985). A lightweight gravity corer for undisturbed sampling of soft sediments. Canadian Journal of Earth Sciences 22, 133-135.

Postgate, J. R. (1984). The Sulphate-reducing Bacteria, 2nd edn. Cambridge: Cambridge University Press.

SANSONE, F. J. (1986). Depth distribution of shortchain organic acid turnover in Cape Lookout Bight sediments. Geochimica et cosmochimica acta 50, 99105.

SAnsone, F. J. \& MARTens, C. S. (1981 $a$ ). Determination of volatile fatty acid turnover rates in organicrich sediments. Marine Chemistry 10, 233-247.

SAnsone, F. J. \& Martens, C. S. (1981b). Methane production from acetate and associated methane fluxes from anoxic coastal sediments. Science 211, 707-709.

Shaw, D. G., Alperin, M. J., ReeburGh, W. S. \& McINTOSH, D. J. (1984). Biogeochemistry of acetate in anoxic sediments of Skan Bay, Alaska. Geochimica et cosmochimica acta 48, 1819-1825.

SKYRING, G. W., JoNEs, H. E. \& GoOdChILd, D. (1977). The taxonomy of some new isolates of dissimilatory sulfate-reducing bacteria. Canadian Journal of Microbiology 23, 1415-1425.

SMITH, R. L. \& KLUG, M. J. (1981). Electron donors utilized by sulfate-reducing bacteria in eutrophic lake sediments. Applied and Environmental Microbiology 42, 116-121.

Sørensen, J., Christensen, D. \& Jørgensen, B. B. (1981). Volatile fatty acids and hydrogen as substrates for sulfate-reducing bacteria in anaerobic marine sediment. Applied and Environmental Microbiology 42, 5-11.

Stams, A. J. M., Hansen, T. A. \& Skyring, G. W. (1985). Utilization of amino acids as energy substrates by two marine Desulfovibrio strains. FEMS Microbiology Ecology 31, 11-15. 
Stanley, S. O., Botok, K. G., Alongi, D. M. \& GillaN, F. T. (1987). Composition and bacterial utilization of free amino acids in tropical mangrove sediments. Marine Chemistry 22, 13-20.

TAYLOR, J. \& PARKES, R. J. (1985). Identifying different populations of sulphate-reducing bacteria within marine sediment systems, using fatty acid biomarkers. Journal of General Microbiology 131, 631-642.

Thauer, R. K., Jungerman, K. \& Decker, K. (1977). Energy conservation in chemotrophic anaerobic bacteria. Bacteriological Reviews 41, 100-180.

WIDDEL, F. (1980). Anaerober Abbau von Fettsäuren und
Benzosäure durch neu isolierte Arten Sulfat-reduzierender Bakterien. Doctoral thesis, University of Gottingen, FRG.

Widdel, F. \& Pfennig, N. (1984). Dissimilatory sulfate- or sulfur-reducing bacteria. In Bergey's Manual of Systematic Bacteriology, vol. 1., pp. 663679. Edited by N. R. Krieg, Baltimore \& London: Williams \& Wilkins.

WINFREY, M. R. \& WARD, D. M. (1983). Substrates for sulfate reduction and methane production in intertidal sediments. Applied and Environmental Microbiology 45, 193-199. 